\title{
WHO SHOULD BEAR THE MATERIAL RESPONSIBILITY FOR DAMAGE OR DESTRUCTION OF IMMOVABLE PROPERTY DURING ARMED CONFLICT? LESSONS FROM SYRIA FOR EUROPE
}

\author{
ХТО ПОВИНЕН НЕСТИ МАЙНОВУ ВІДПОВІДАЛЬНІСТЬ ЗА ПОШКОДЖЕННЯ \\ АБО ЗНИЩЕННЯ НЕРУХОМОСТІ В ХОДІ ЗБРОЙНОГО КОНФЛІКТУ? \\ УРОКИ СИРІї ДЛЯ ЄВРОПИ
}

\author{
Spiesivtsev D.S., PhD in Law, \\ Senior Lecturer at the Department of Civil Law Disciplines \\ Lesya Ukrainka Volyn National University
}

The article is devoted to consideration of the general problems of protection of property rights to real estates that were damaged or destructed during the armed conflict. It is defined that as of October 21, 2017, more than 10,000 buildings were damaged in Syrian city of Ar-Raqqa, and 3.326 were destroyed. Also in Aleppo were destroyed 4.733 buildings as well as 6.133 in Eastern Ghouta. The same damage was caused in other cities. This actualizes the question to who should bear the responsibility for such damage and what are the juridical mechanisms of its compensation?

The author concludes that the situation in Syria clearly shows that internal armed conflict is associated with a high probability causing of property damage to the civilian population and legal entities. It is likely that recognition at the national level of the parties to the conflict, in addition to government forces, as violators in the manner established by the national law will lead to corresponding negative consequences for them. Particularly, person, who damaged or destroyed immovable property, is obliged to compensate appropriate damage as the offender.

At the same time in the event that a state acts as an aggressor, individuals and entities whose real property has been damaged or destroyed during the conflict can claim compensation directly from such state (in case of use of national and international protection which characteristic of European countries) or to receive compensation from the state in respect of which an act of aggression has been committed. In its turn, defending state, with the help of reparations, may transfer to the aggressor all or a significant part of the damage that the population noted in the course of the conflict, even if such damage was caused by their own government troops in the course of the defense. But it important to admit that in second of mentioned situations there can be no juridical responsibility of defending state in cases when there is no causal relation between actions of such state and the damage. Thus in such situation the amount of compensation can be less than amount of the damage.

Key words: immovable property, real estate, armed conflict, damage, destruction, compensation.

Стаття присвячена розгляду загальних проблем захисту суб'єктивних цивільних прав на нерухоме майно, що пошкоджене або знищене в ході збройного конфлікту. Установлено, що станом на 21 жовтня 2017 року більше ніж 10000 будівель пошкоджено в сирійському місті Ар-Ракка та 3326 знищено. Також в Алеппо знищено 4733 будівлі, а в Східній Гутті - 6133. Схожі пошкодження зазнали й інші міста Сирійської Арабської Республіки. Окреслене актуалізує питання, хто повинен нести відповідальність за цю шкоду та яким є юридичний механізм її відшкодування?

Автор доходить висновку, що ситуація, яка склалася в Сирії, чітко показує, що внутрішньодержавний збройний конфлікт пов'язується з високою ймовірністю завдання майнової шкоди цивільному населенню, а також юридичним особам. Визнання на національному рівні учасника конфлікту порушником у спосіб, визначений положеннями національного законодавства, призводить до відповідних негативних наслідків для нього. Зокрема, особа, яка пошкоджувала або знищувала нерухомість, зобов'язана відшкодувати відповідну шкоду як деліквент.

Водночас у випадку, коли держава діє як агресор, фізичні та юридичні особи, чия нерухомість була пошкоджена або знищена в ході збройного конфлікту, можуть вимагати відшкодування безпосередньо від агресора (у випадку застосування національного й міжнародного захисту, що характерний для країн Європи) або отримати компенсацію від держави, стосовно якої здійснено акти агресії. Своєю чергою, держава, яка обороняється, за допомогою інструмента репарацій може перекласти на агресора або відповідну сторону конфрлікту ввесь розмір шкоди, яку зазнало населення в ході збройного конфлікту, зокрема й ту, що завдана урядовими військами в ході захисту. Водночас важливо відмітити, що в другому з описаних випадків може не наставати юридична відповідальність держави, що захищається, зокрема, якщо відсутній причинно-наслідковий зв'язок між діями такої держави та завданою шкодою. У такому разі розмір компенсації може бути нижчим за розмір завданих збитків.

Ключові слова: нерухоме майно, нерухомість, збройний конфрлікт, пошкодження, знищення, відшкодування.

Problem statement. The situation in Syria highlights a new level of danger for property rights in a multilevel and multi-faceted armed conflict. This situation is interesting because on the territory of the Syrian Arab Republic, in which the government and the opposition troops participate, the terrorist groups, whose activities in all episodes of the conflict have all the signs of terrorist activity, have joined the internal conflict.

In connection with the armed actions in Syria, questions arise as to who should bear the responsibility for the damage caused to the property particularly to immovable property of the civilian population and legal entities, in the context of the armed conflict, and what is the juridical mechanism for its reimbursement. The provisions of international conventions and declarations do not clearly answer the questions raised. In addition, at the moment, there are virtually no international standards that would determine a clear mechanism for compensation for damage caused by armed actions.

It is believed that the introduction of the compensation procedure is associated with the need to fix a clear formula for determining the subject of indemnity. It is this part of the entire compensation mechanism that is most difficult to establish, as it relates to the dynamics of damage caused by several participants in the conflict at once [1, p. 72].

Literature review. The problems of material responsibility for the damage caused to the property, particularly real estates of the civilian population and legal entities or for destruction of such material things became an object of consideration of G.M. Amfiteatrov, J. d'Aspremont, A.M. Ball, J. von Bernstorff, D.B. Carter, I. Couzigou, M.L. Duvernois, J.H. Gardner, D. Graeber, W. Heckel, M. Khomenko, A. Kostruba, O. Kot, R. Müllerson, A. Najjar, A. Nollkaemper, S.Plakokefalos, C. Ryngaert, T. Tzimas, Q. Whitman and others.

The civil law aspects of getting booty during the armed interstate conflicts and its juridical regime were the object of researches of M.L. Duvernois. Considerable attention was paid in his works to preferential rights of state in acquiring property including territories during military campaigns.

Juridical problems of protection of property rights of Soviet people after World War II considered by G.N. Amfiteatrov particularly in context of judicial protection. 
Among the modern Ukrainian researches A. Kostruba and $\mathrm{O}$. Kot pay their attention to research the problems of protection of human rights in civil law context.

But despite of that many problems of protection of property rights related to damage or destruction of real estates during the armed conflicts stay unresearched.

Purpose. The main purpose of the article is to outline the general problems of protection of property rights to real estates that were damaged or destructed during armed conflict.

Research results. The main problems of issues aroused are the control over the territory and the functions of the state in context of armed conflicts. In particular, control over the locality may be established by one of the parties to the conflict (government troops, opposition troops or terrorist groups) without seriously compromising the property of civilians and legal entities, in particular immovable, but with further attempts to establish or renew the control of the relevant territory by the other party the conflict can cause significant damage to the real estates, as the defending party can use the buildings and structures to arrange combat positions and fire points that become the target of heavy weapons $[1$, p. 72].

For an example of the situation, you can take the Syrian city of Ar-Raqqa, the density of property damage in which per unit area is the largest among all the Syrian cities during the entire period of the conflict [2]. In particular, since the beginning of the conflict, the city was under the control of the armed opposition groups, but in November 2014, militants of the Islamic State in the course of fighting set control over the city. In June 2017, the Syrian Democratic Forces, supported by the coalition led by the United States, carried out a military operation accompanied by a bombing of the city, resulting in the destruction of many schools, hospitals and other infrastructure of the city. As of October 21, 2017 , more than 10,000 buildings were damaged in the city, and 3,326 were destroyed [3, p. 13-14].

Similarly, in Eastern Ghouta, which was considered the stronghold of the opposition forces, government forces, using attempts to clear the city from rebels, used heavy weapons and aircraft. As a result, because of hostilities on the territory of Eastern Ghouta, as of October 21, 2017, 6.133 buildings were destroyed. In Aleppo, which was conditionally divided in the course of the western-backed conflict, controlled by the government forces, and the eastern, controlled by the opposition forces, destroyed 4.733 buildings, mainly in the eastern part of the city, resulting from the use of heavy weapons and bombing [3, p. 9-10, 15-16].

Thus, property damage inflicted in the course of an armed conflict on private property can be quite significant, which raises the question of determining the subject of liability and the procedure for reimbursement of the damage.

First of all, the Syrian Issue has shown an acute shortage of effective instruments of international judicial protection of the subjective rights of persons who suffered from hostilities on the territory of the Syrian Arab Republic. Thus, this issue is fully subjected to the jurisdiction of national courts, the most effective of which is possible only as a result of the complete collapse of the conflict. Along with this, armed actions in Syria also outlined potential threats to the international system of property rights protection for the countries party to the Convention for the Protection of Human Rights and Fundamental Freedoms (1950) (hereafter the Convention). The extrapolation of the model of conflict that takes place in Syria to the territory of one of the European countries is a clear demonstration of these challenges. At the same time, the reality of these threats is demonstrated by the armed conflict that is taking place in Eastern Ukraine.

In addition, in the context of Syria, it is seen that in the absence of clear international legal mechanisms for compensation for damage caused by armed actions, the search for answers to the questions raised leads us to national legislation and to the legal basis of property liability. And here, most likely, we will witness the final resolution of the relevant issue post factum of the end of the conflict, that is, when the situation will qualify either from the point of view of the law of the state in the territory of which the conflict occurs or from the perspective of the winner who can change the rules. To some extent here will find the embodiment of the words "the winners are not judged." Let's explain why.

As you know, the conflict that is taking place in Syria is characterized by multilateralism. It is attended by government troops, opposition forces and terrorist organizations (recognized by many countries in the world at least). The extent of the damage done is enormous, entire areas of cities with infrastructure and private and public real estate are destroyed. It is necessary to look at the outlined situation in the eyes of each participant in the conflict.

1. Government troops. In the conflict government troops represent the Government of Syria. In the context of the established tradition of writing the texts of the Criminal Codes, special attention is given to the protection of state power in the relevant normative legal acts. This is manifested in the recognition of criminal and the establishment of responsibility for actions aimed at changing or overthrowing the constitutional order or in capturing state power, encroachment on territorial integrity and inviolability, state betrayal, etc. The actions taken from the point of view of the ruling authorities and the current law make the person concerned a criminal, and therefore open the opportunity to bring him to justice $[1$, p. 73$]$. In addition, there is always a possibility for the acting authorities to declare a mertial law or a special period, for example, an anti-terrorist operation. As a result, the liberation of cities from terrorists will be considered legal. The damage caused by military formations of power is considered as a necessary measure.

However, it is evident that the social function naturally inherent in the state requires the implementation of the necessary reimbursement by the state concerned with the possibility of their recovery from the armed organizations $[1$, p. 73$]$.

But in context of Europe we need to admit that the European Court of Human Rights (hereafter - the ECHR) in case Esmukhambetov and Others v. Russia (application no 23445/03) has established that: "The air raid having resulted in the destruction of a number of buildings in the village of Kogi, it was clear that there had been an interference with the applicants' rights under Article 8 and Article 1 of Protocol No. 1. As regards the lawfulness of the interference, the Government had referred to the Suppression of Terrorism Act as a legal basis. The Court had already noted in other cases concerning the conflict in the Chechen Republic, that that Act did not define with sufficient clarity the scope of those powers and the manner of their exercise so as to afford an individual adequate protection against arbitrariness. The law could not serve as a sufficient legal basis for such a drastic interference as the destruction of an individual's housing and property. The interference with the applicants' rights had not been "lawful", within the meaning of Article 8 of the Convention and Article 1 of Protocol No. 1. There had accordingly been a violation of Article 8 of the Convention and Article 1 of Protocol No. 1" [4].

2. Opposition forces. These divisions are united by the common goal of changing power in the country. In case of their coming to power, the most optimal for these forces will be the announcement of an amnesty for participation in an armed conflict at least on the opposition side as it has been done in Ukraine after the Revolution of Dignity, but within the framework of the de-escalation of the conflict, an amnesty could be announced to all participants, except those who committed war crimes.

One of the possible options for behavior will be the persecution of the previous authorities, in particular with a view to identifying fortunes for their return to the state treasury to restore the state of the economy and to compensate 
for damages and destruction of real estates. Nevertheless, with such developments, there is an almost inevitable probability that the armed conflict will be recognized as a legitimate means for further development at the level of state legislation.

Nevertheless, the burden of rebuilding destroyed cities will be imposed on the state, which in fact means its placement on the population of the country under the mechanism of funds and direct compensation.

3. Terrorist groups. They represent separate groups of people, united by the common purpose of spreading ideological dogmas to a certain territory. Today, this issue is the most urgent, since such groups are fragmented, and those who directly damage their property may not have the necessary means to recover it, or such person may at all perish during an armed conflict. Sometimes it is quite difficult to define who carried out the direct destruction of the property concerned. The massive involvement of the relevant units in the armed conflict shows that the Syrian authorities after the conflict will face the same challenges that are currently being addressed by the counterterrorist states, including the search for terrorist financing channels, their liquidation, the forfeiture of their property, the identification of individuals, involved in the following activity, conducting their criminal prosecution.

On this occasion, Declaration of Basic Principles of Justice for Victims of Crime and Abuse of Power adopted on November 29, 1985, that the perpetrators or third parties are responsible for their behavior and should provide fair compensation to victims, their families and dependents. Such restitution, in particular, includes the return of property, compensation for damage, etc. (paragraphs 8, 9). In addition, the Declaration encourages the creation of national funds to compensate for the damage done to the victims, as well as the provision of necessary, including material assistance to the victims by the state (paragraphs 13, 14) [5].

Conclusions and perspectives of further researches. Thus, the situation in Syria clearly shows that internal armed conflict is associated with a high probability causing of property damage to the civilian population and legal entities.

It is likely that recognition at the national level of the parties to the conflict, in addition to government forces, as violators in the manner established by the national law will lead to corresponding negative consequences for them. Particularly, person, who damaged or destroyed immovable property, is obliged to compensate appropriate damage as the offender.

In addition, the social function of the state will stipulate the necessity of reimbursement to persons who have been victims of an armed conflict in connection with which such compensation may be carried out in kind, in particular, by providing free accommodation to other persons (in case of loss of dwelling) and granting material compensation. Such a reimbursement by the State will not deprive it of its ability to recover the funds from other parties to the conflict. However, this will be difficult, because finding such persons is quite difficult. Participants in the conflict on the side of the opposition or terrorist groups are heterogeneous groups, but in essence, individuals. To find all of them and to define the nature of their participation in abovementioned actions is virtually impossible.

In this case, it should be noted that in this situation the Syrian authorities are faced with a very serious legal problem.

First of all, this is the completeness of the refund. As a rule, it is difficult or practically impossible to achieve. The proposed new housing may differ from the lost, there will be difficulty in determining the cost of the selected things, etc. At the same time, it is practically impossible to make appropriate compensations simultaneously to all persons in full, taking into account the economic situation of the state after the conflict.

The second issue will be to establish the exact extent and degree of participation of each of the parties to the conflict in the destruction of property. The problem is that in practice it is objectively impossible to establish the degree of guilt of the relevant individuals in the destruction of the relevant objects. As described above, property could have been destroyed either by government forces or by opposition forces or by terrorist groups or by joint actions. It is virtually impossible to establish the responsible entity and the extent of its responsibility. In this regard, practically all the burden of reimbursement will be relied upon by the state with the possibility of further recovery of the corresponding damage from other parties to the conflict [1, p. 73-74].

The introduction by the European countries of the national and international levels of the system of protection of property rights, access to which practically any individual or legal person has, while taking over the obligations of the States parties to the Convention to guarantee to everyone under their jurisdiction the rights and freedoms, as defined in section I of the Convention, has changed the perceptions of a just war.

The social function of the state in any case obliges to assist in the restoration of violated rights, however, if earlier the victimized state could count on reparation from the aggressor, in the modern conditions the character of the calls has changed. Dangerous for the state are aggressive separatist manifestations, which are connected with the refusal of political solution of the issue in favor of armed confrontation. Similarly, in the Middle East, terrorist threats, which are not limited to single acts of terrorism, are more serious, but are linked with attempts to form a state education.

The main problem is that in the event that a state acts as an aggressor, individuals and entities whose real property has been damaged or destroyed during the conflict can claim compensation directly from such state (in case of use of national and international protection which characteristic of European countries) or to receive compensation from the state in respect of which an act of aggression has been committed. In its turn, defending state, with the help of reparations, may transfer to the aggressor all or a significant part of the damage that the population noted in the course of the conflict, even if such damage was caused by their own government troops in the course of the defense. But it important to admit that in second of mentioned situations there can be no juridical responsibility of defending state in cases when there is no causal relation between actions of such state and the damage. Thus in such situation the amount of compensation can be less than amount of the damage.

At the same time in cases when the other country is included to the interstate conflict in particular, by supplying of weapons and/or ammunition the defending party can lead it voluntarily to arbitration. In this context the example is the famous arbitration case between the United Kingdom and the USA had served primarily to regulate compensation for private loss of property during the revolutionary wars between the two states on the basis of the Jay Treaty or of the disputes resulting from the UK's involvement in the US civil war, such as the Alabama arbitration [6, p. 243].

Moreover when the part of the territory is occupied by the other country all the damages caused by occupation could be imposed on the occupier. In the case of Cyprus v. Turkey the ECHR expressed the position was with regard to interstate compensation for the occupation by Turkey of the territory of northern Cyprus (Application no. 25781/94) [7]. Thus, the Court has formed a very important conclusion that not only individuals, but the state, can expect compensation for pecuniary damage.

However, if a separatist or terrorist group takes part in the conflict, it is difficult for a state to receive compensation they may have no property for the reparation of the harm done.

In this regard, in the context of modern threats to the ownership of domestic conflicts and hybrid wars related to the use of armed force, the main means of counteraction must pull out the power struggle, as well as powerful instruments of legal and economic counteractions that participate in such a conflict is economically disadvantageous or burdensome. 
In particular, in the context of ECHR practice, there is a need for the functioning of the national level not only of laws that criminalize combat participation as a combatant (which is presently practically in every country in Europe) but also the establishment of a national mechanism for the definition of subject of liability and the order of compensation for damage inflicted on private property. Given the complexity of defining the subject of causing such damage, the most effective indirect compensation mechanisms are that the damage is reimbursed by the state, in particular from special funds, with the possibility of recovering the corresponding damage from other parties to the conflict and those who committed the corresponding crimes.

\section{REFERENCES}

1. Spiesivtsev D. Protection of Property Right to Real Estate: Modern Problems in the Context of the Conflict in Syria. Aктуальні питання реформування правової системи : збірник матер. XVIII Міжнар. наук-практ. конф. (м. Луцьк, 5 чер. 2021 р.). Луцьк : Завжди Поруч, 2021. C. 72-74.

2. Najjar A. Damage Caused by the Syrian Civil War: What the Data Say. URL: https://towardsdatascience.com/damage-caused-by-thesyrian-civil-war-what-the-data-say-ebad5796fca8 (access date: 30.06.2021).

3. Syria. Syrian Cities Damage Atlas. Eight Year Anniversary of the Syrian Civil Law. Thematic Assessment of Satellite Identified Damage" (16 march 2019) / UNITAR, 2019. 71 p. URL: https://reliefweb.int/sites/reliefweb.int/files/resources/reach_thematic_assessment_syrian_cities_ damage_atlas_march_2019_reduced_file_size_1.pdf (access date: 21.05.2021).

4. Judgment of the European Court of Human Rights, 2011, no. 273. Esmukhambetov and Others v. Russia (application no. 23445/03). URL: https://hudoc.echr.coe.int/eng-press\#\{\%22itemid\%22:[\%22003-3487263-3928922\%22]\} (access date: 30.06.2021).

5. Declaration of Basic Principles of Justice for Victims of Crime and Abuse of Power proclaimed by the United Nations General Assembly 29.11.1985: General Assembly resolution A/RES/40/34. URL: https://www.un.org/documents/ga/res /40/a40r034.htm (access date: 21.05.2021).

6. Bernstorff J. von. The Use of Force in International Law before World War I: On Imperial Ordering and the Ontology of the Nation-State. The European Journal of International Law. 2018. Vol. 29. Issue 1. P. 233-260.

7. Judgment of the European Court of Human Rights, 2014, no. 25781/94, Cyprus v. Turkey (application no. 25781/94). URL: https://hudoc.echr.coe.int/eng\#\{\%22itemid\%22:[\%22001-144151\%22]\} (access date: 30.06.2021). 